J. Perinat. Med. 17 (1989) 85

\title{
Fetal cardiac time intervals determined by Doppler echocardiography
}

\author{
Toshiyuki Hata, Daisaku Senoh, Ken Makihara, Showa Aoki, Kohkichi Hata, Osamu \\ Takamiya, and Manabu Kitao
}

Department of Obstetrics and Gynecology, Shimane Medical University, Izumo, Japan

\section{Introduction}

When the radionuclide labeled microscophere methods was used, the percentages of combined ventricular output distributed to various organs in the term fetal lamb were found to be: placenta 41, lungs 7, kidney 2, myocardium 3.6, brain 3 and gastrointestinal tract 5.5 [18]. Therefore, the afterload of in utero fetal heart is mainly determined by vascular resistance of the placenta and lungs. In normal ovine pregnancies, umbilical placental circulation resistance has been found to decrease with increase in gestational age [2]. In a human pregnancy, a decrease in the $\mathrm{A} / \mathrm{B}$ ratio of umbilical artery blood flow velocity waveform obtained with Doppler ultrasound is thought to indicate the same change [21]. A study on fetal lambs suggested a linear relationship between pulmonary vascular resistance and the $\mathrm{PO}_{2}$ to which the vessels are exposed [1] and the pulmonary blood flow increased in proportion to the increase in fetal weight during advance in gestation [18].

Recent advances in Doppler ultrasound have made feasible the assessment of in utero fetal cardiac circulatory hemodynamics $[4,7,12]$. Consequently, peak velocities of intracardiac and great vessel blood flow, stroke volume and cardiac output have been calculated [5, 6, 8, 16, 17]. In adults and children, noninvasive evaluation of pulmonary hypertension by a pulsed Doppler technique has been reported and the time to peak flow (acceleration time, AT) and AT/ventricular ejection time (ET) ratio correlated negatively with systolic pulmonary artery pressure, respectively $[9,10]$. In subjects with a normal pulmonary artery pressure, the blood flow pattern in systole showed a gradual acceleration and deceleration with a rounded sum-

\section{Curriculum vitae}

TOShiYuki Hata, M. D., was born in 1953. He graduated from Mie University School of Medicine in 1980. Since November 1987 he has been an assistant professor in the Department of Obstetrics and Gynecology, Shimane Medical University. His main fields of interest include fetal cardiology and Doppler ultrasound in Obstetrics and Gynecology.

mit in mid systole, however, in patients with pulmonary hypertension there was a rapid acceleration and an early deceleration with a sharp peak in early systole [15]. In the present study, we used Doppler ultrasound and analyzed blood flow patterns in the aorta and the pulmonary artery, with special reference to changes in placental and pulmonary vascular resistances with advancing gestation.

\section{Materials and methods}

One-hundred and eleven pulsed Doppler ultrasound examinations were performed on 88 normal fetuses, ranging from 16 to 41 weeks of gestation. All the mothers were Japanese and permission was obtained from each one for the study. Data on factors related to menstruation corresponded with physical examination and ultrasound estimation 
of gestational age, determined by measuring biparietal diameter [14] and fetal femur length [22]. All were normal infants at birth and birth weights were within normal ranges (between the 10th and 90th percentile) to the standard growth curve for the Japanese [19].

The apparatus used was an Aloka SSD-870 with a $3.5-\mathrm{MHz}$ transducer. An Aloka SSD-870 is applicable for either pulsed or real-time two-dimensional Doppler modes. In the pulsed Doppler mode, velocities can be measured up to $6.2 \mathrm{~m} / \mathrm{sec}$ with a $3.5-\mathrm{MHz}$ transducer and the sampling volume length was $0.1 \mathrm{~cm}$. This apparatus also allows for a simultaneous real-time imaging and Doppler tracing capabilities. Wall filters $(200 \mathrm{~Hz})$ were used to eliminate the low-frequency signals occurring from valve signals and from all noise. Both the pulsed and real-time two-dimensional Doppler mode can be operated at a power output of less than $100 \mathrm{~mW} / \mathrm{cm}^{2}$ special peak-temporal average, according to the manufacturers' specifications.

The real-time two-dimensional Doppler mode was used to position the sampling volume of pulsed Doppler mode in the region of interest, where the blood flow velocity was to be measured. The sampling volume was placed in the great arteries immediately distal to the semilunar valves where the ultrasound beam was parallel to the direction of blood flow shown by Doppler color flow mapping. Therefore, the angle between the direction of blood flow and the Doppler beam $(\theta)$ is assumed to be 0 because the Doppler beam is kept in parallel to direction of the blood flow [6]. In systole, a sharp peak blood flow velocity waveform was distinct in aortic and pulmonary blood flow velocity waveforms (figure 1). The maximal velocity of blood flow (MV) can be calculated by the Doppler equation: $V=(\Delta f \cdot C) /(2 f \cdot \operatorname{Cos} \theta)$, where $\mathrm{V}=$ maximal velocity, $\Delta \mathrm{f}=$ frequency shift, $\mathrm{f}=$ transmitted ultrasound frequency and $\mathrm{C}=$ speed of sound in tissue $[6,13]$. The AT was defined as the interval between the onset of ejection and maximal velocity and the ET as the time from the onset of ejection to that of zero flow [9]. The MV/ AT (acceleration velocity: AV) and AT/ET ratio were also calculated. On each record, 4 to 5 separate cardiac cycle were examined to determine the mean maximal velocity.

\section{Results and comment}

Aortic MV and pulmonary MV correlated well with gestational age (figures 2 and 3). Good correlations between aortic AT, pulmonary AT and gestational age were evident (figures 4 and 5).

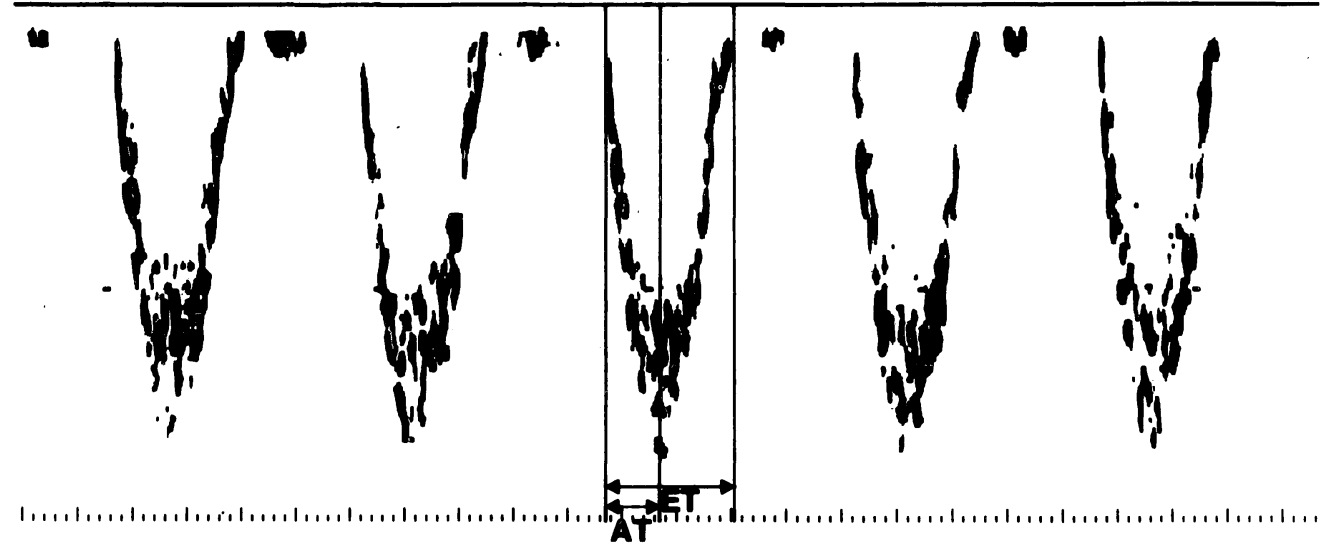

Figure 1. Pulmonary blood flow velocity waveform, in the in utero fetus. AT: acceleration time, ET: ejection time. 


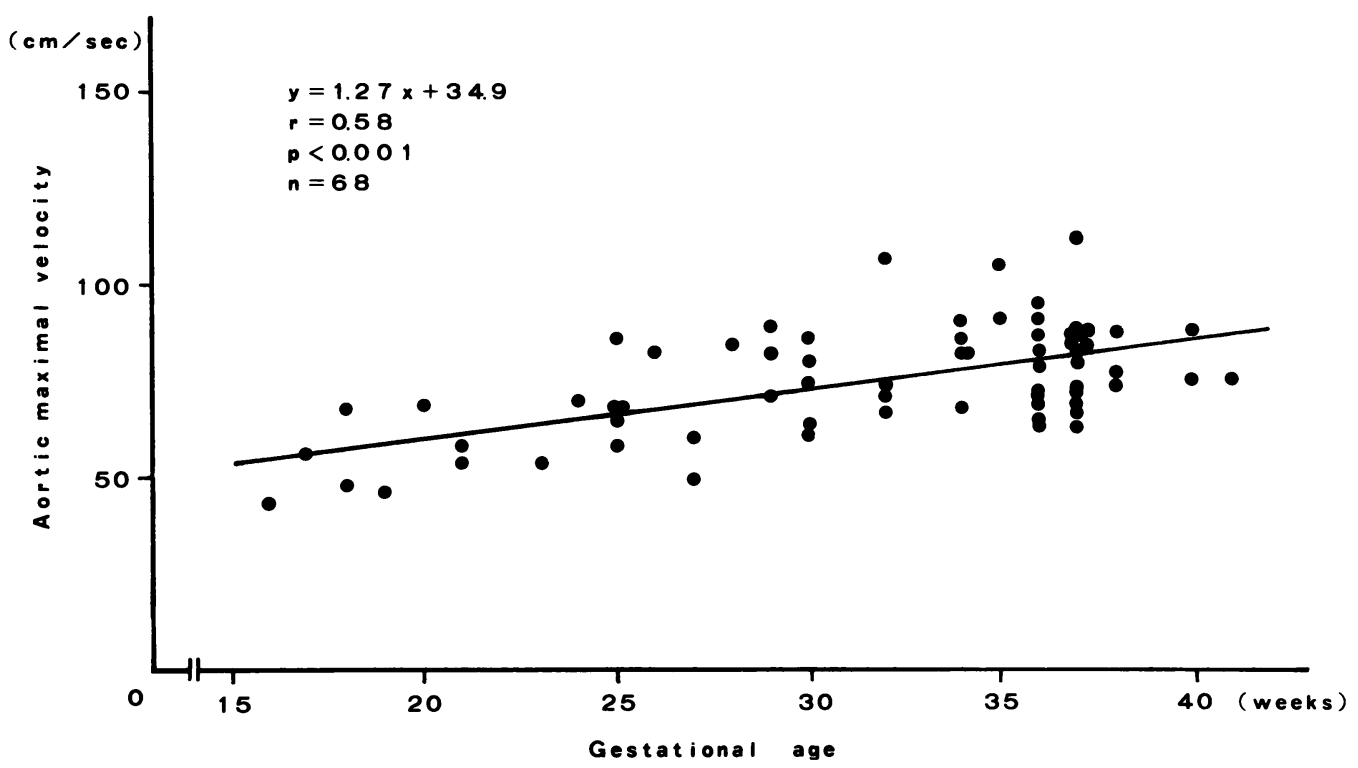

Figure 2. Aortic maximal velocity and gestational age.

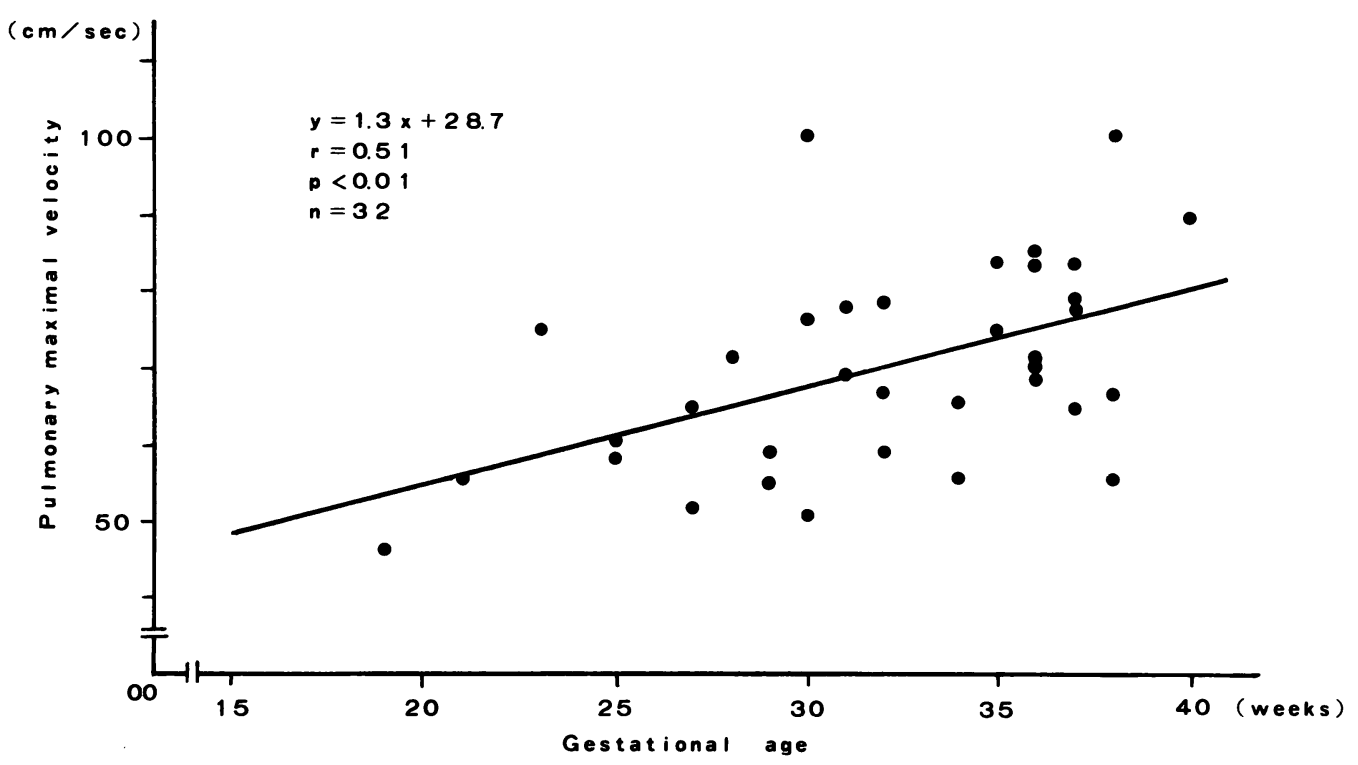

Figure 3. Pulmonary maximal velocity and gestational age.

There were correlations between aortic AT/ET ratio, pulmonary AT/ET ratio and gestational age (figures 6 and 7). There was no correlations between aortic AV, aortic ET, pulmonary AV, pulmonary ET and gestation, respectively.
KitABATAKE et al. [9] reported that either pulmonary AT or AT/ET ratio decreased with increase in pulmonary artery pressure and that a very high correlation was found between pulmonary AT/ET ratio and pulmonary artery pressure in adults, as 


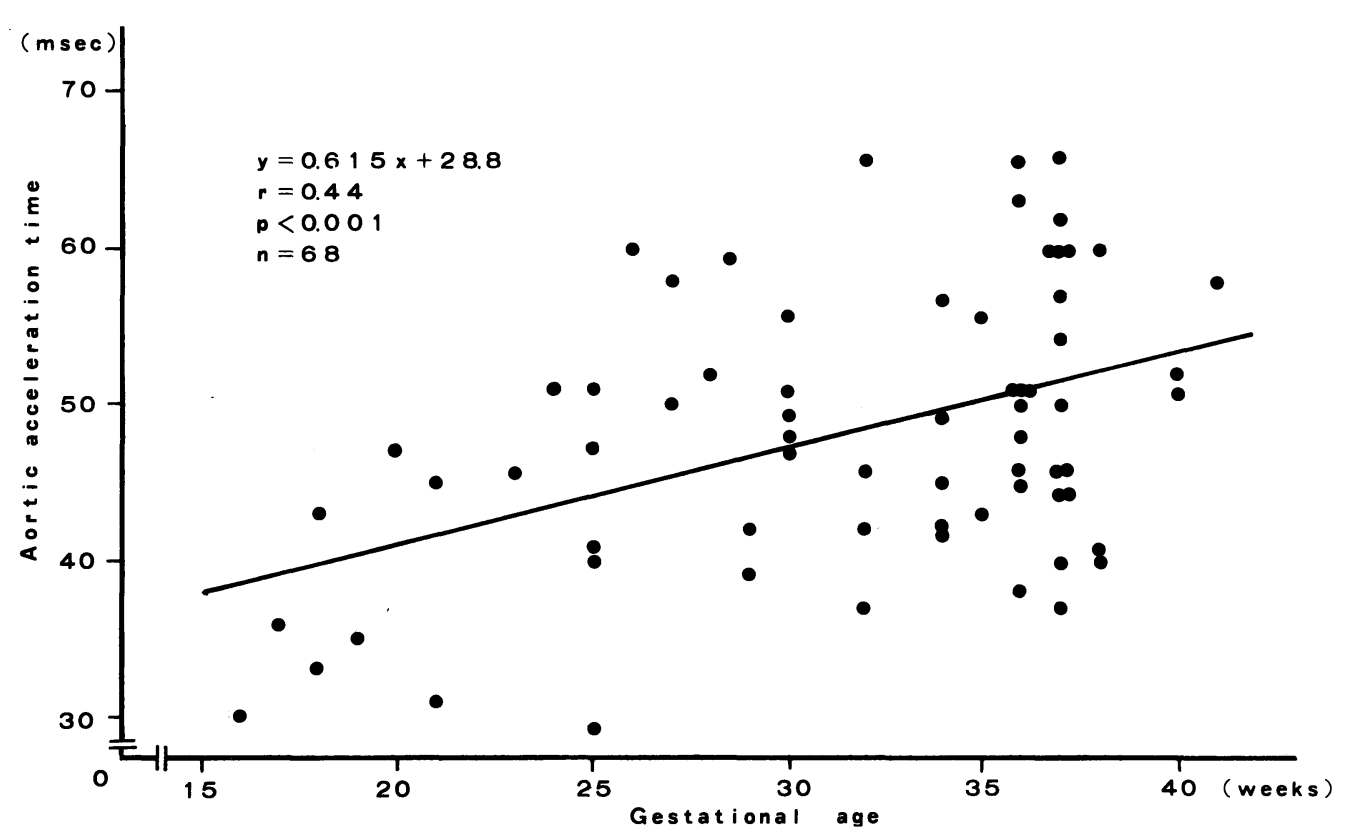

Figure 4. Aortic acceleration time and gestational age.

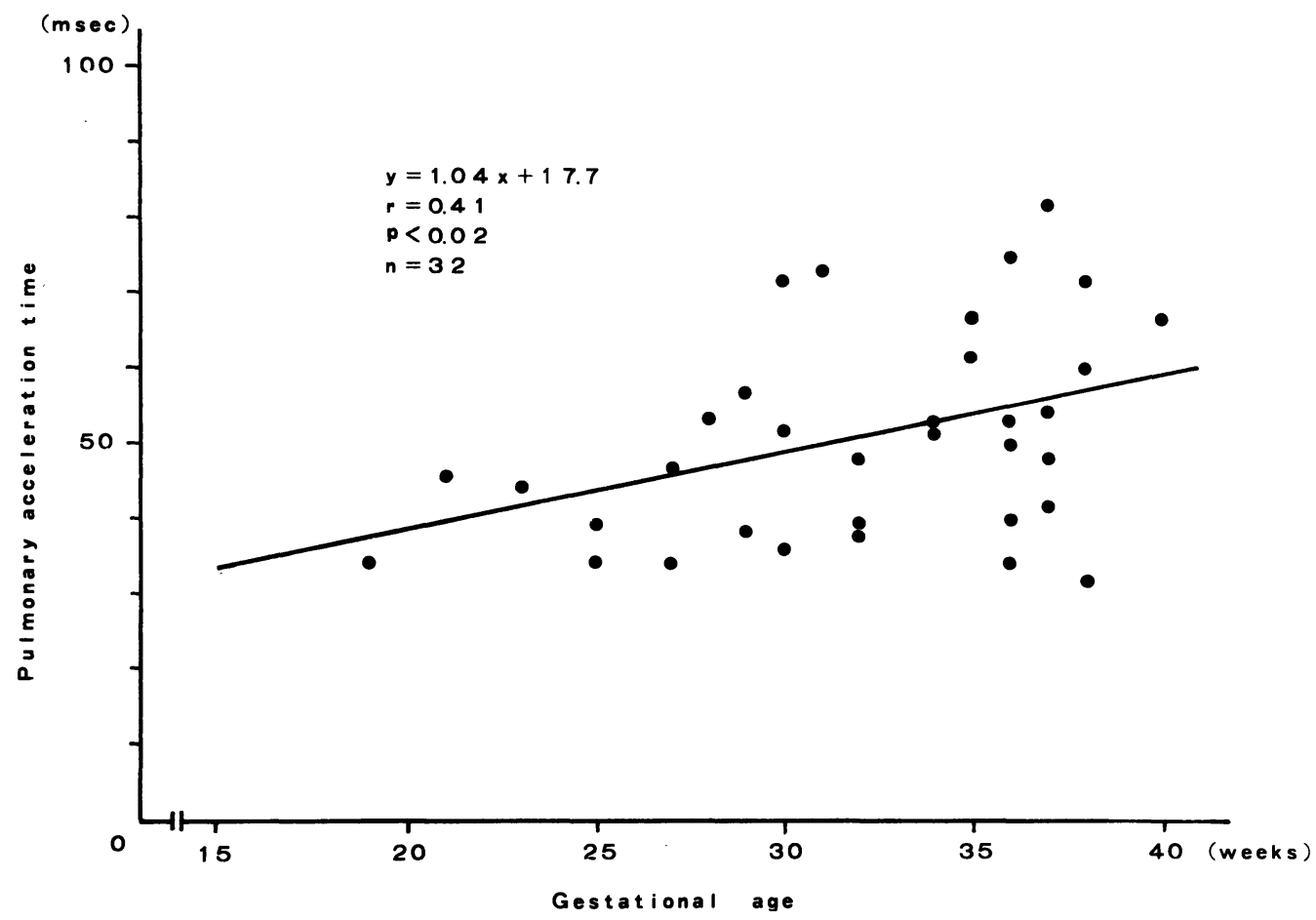

Figure 5. Pulmonary acceleration time and gestational age. 


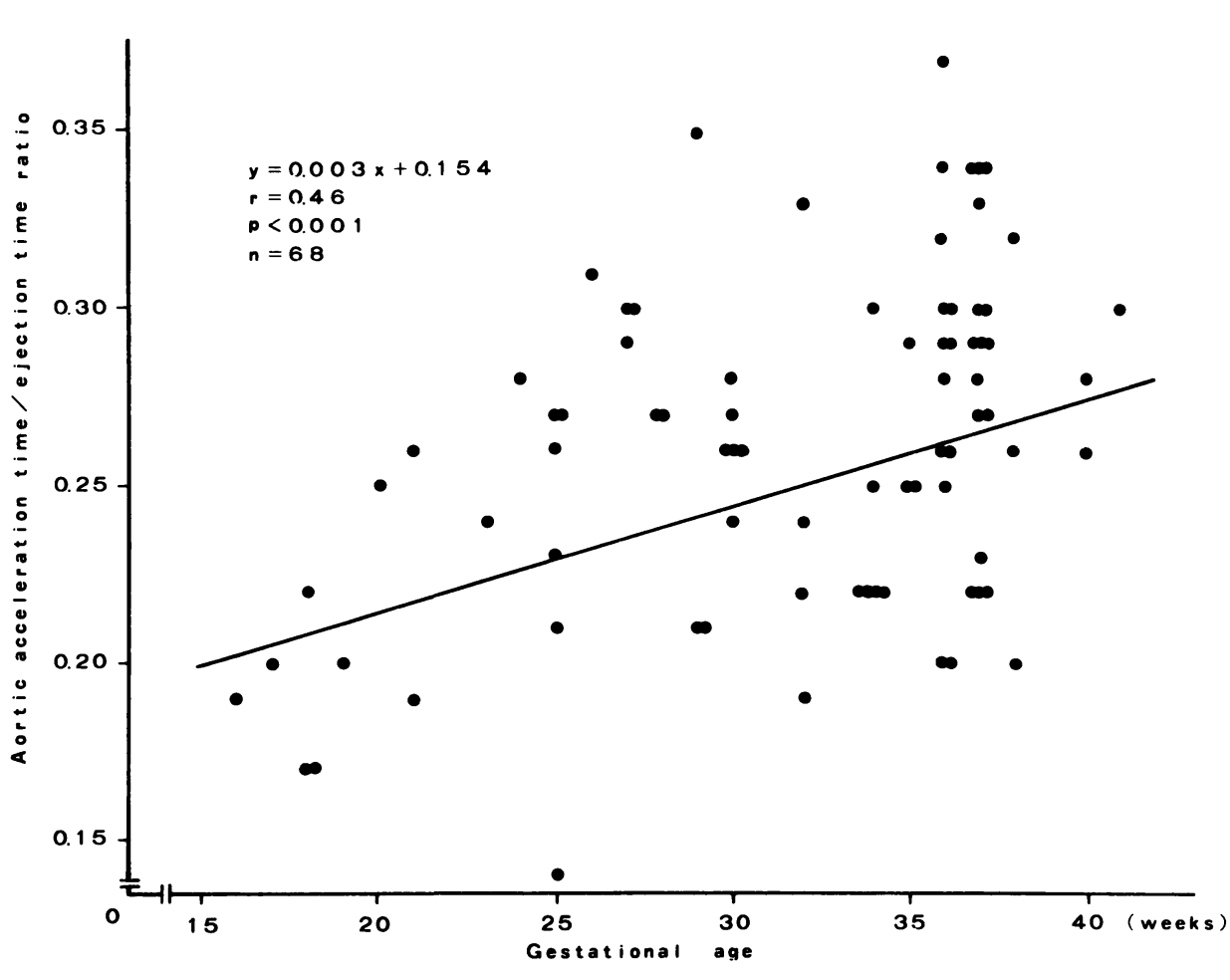

Figure 6. Aortic acceleration time/ejection time ratio and gestational age.

determined by the pulsed Doppler technique and cardiac catheterisation. These findings were confirmed in children, using the same techniques [10, 20]. In subjects with a normal pulmonary artery pressure, the blood flow pattern in systole showed a rounded summit in mid systole (round type), however, in patients with pulmonary hypertension, it showed a rapid acceleration and early deceleration with a sharp peak in early systole (triangular type) [15]. In our study on fetal velocimetry by pulsed Doppler ultrasound, both aortic and pulmonary blood flow velocity waveforms showed the triangular pattern, in all the normal fetuses.

With pulsed Doppler ultrasound, identification and measurement of fetal intracardiac blood flow velocity waveforms have been performed $[4,7,12]$. The aortic and pulmonary MV was found to increase gradually with advancing gestational age, under physiologic conditions [6]. Similarly, in our study, aortic and pulmonary MV correlated well with gestation, respectively. Machado et al. [11] reported no evidence of change in aortic or pul- monary AT with increasing gestation between 16 and 30 weeks' gestation. In the present study, however, aortic and pulmonary AT increased gradually with advancing gestational age from 16 to 41 weeks, respectively. Similarly, aortic and pulmonary AT/ET ratio correlated well with gestation, respectively. In normal ovine pregnancies, umbilical placental circulation resistance has been found to decrease with increase in gestational age [2]. In cases of a human pregnancy, placental resistance falls as pregnancy advances [3, 21], an event which presumably affects the results of aortic AT and AT/ET ratio and pulmonary AT and AT/ET ratio in the normal fetus [11]. Our study showed that the afterload of both aortic and pulmonary artery decreased as did the placental resistance, with increasing gestation. However, there was no change in aortic ET and AV and pulmonary ET and AV with the advance in gestational age. We propose that our observations may relate to change in pulmonary and placental vascular resistance with advancing gestation, in the normal human fetus, in utero. 


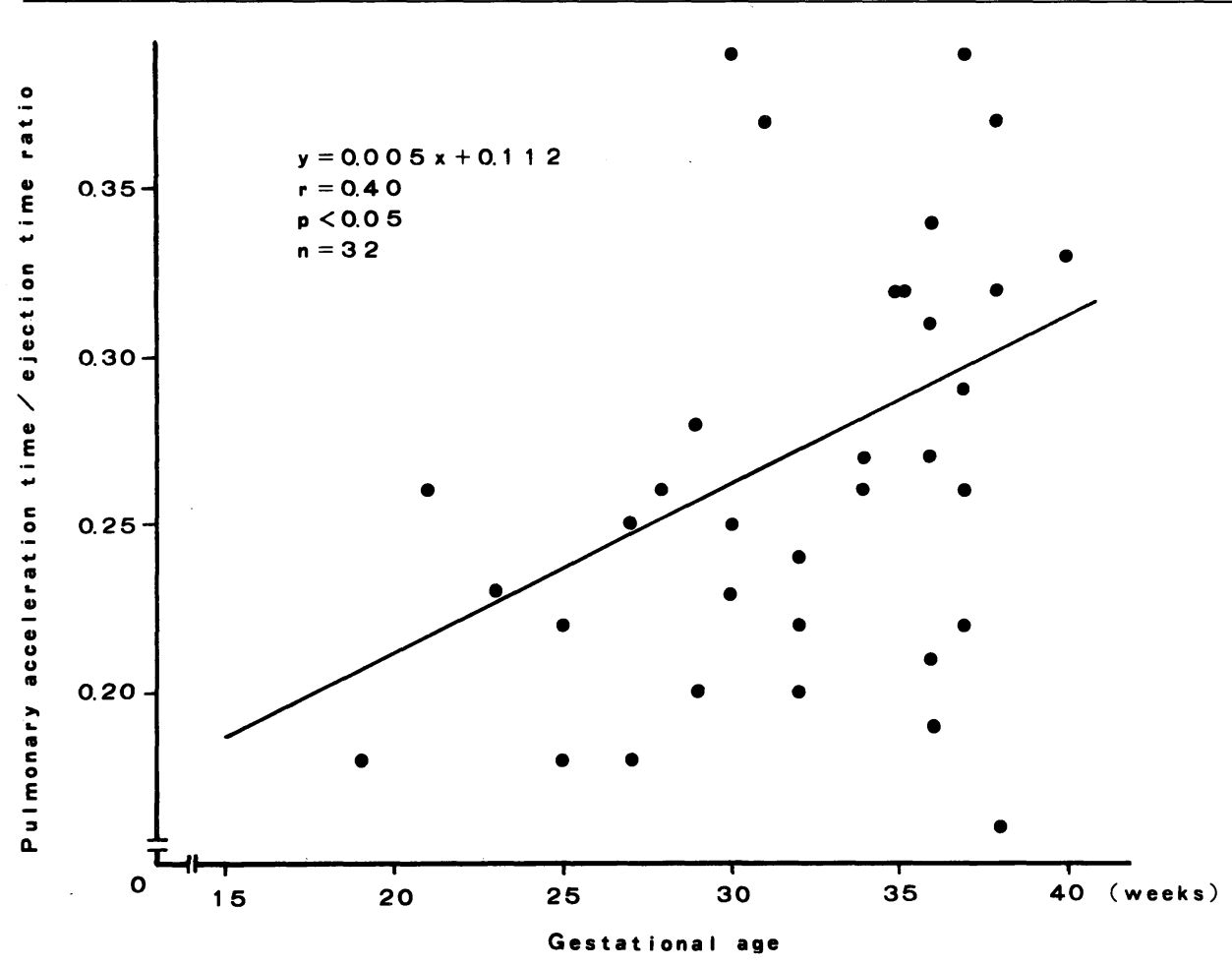

Figure 7. Pulmonary acceleration time/ejection time ratio and gestational age.

\begin{abstract}
One-hundred and eleven Doppler echocardiographic examinations were performed on 88 normal fetuses, ranging from 16 to 41 weeks of gestation. Aortic and pulmonary maximal velocity (MV), acceleration time (AT), ejection time (ET), MV/AT (acceleration velocity: AV) and AT/ET ratio in systole were assessed on each blood flow velocity waveform. Aortic MV and pulmonary MV correlated well with gestational age, respectively. Good
\end{abstract}

correlations between aortic AT, pulmonary AT and gestational age were evident. There were correlations between aortic $\mathrm{AT} / \mathrm{ET}$ ratio, pulmonary $\mathrm{AT} / \mathrm{ET}$ ratio and gestational age, respectively. However, there was no correlation between aortic AV, aortic ET, pulmonary AV, pulmonary ET and gestational age, respectively. These findings may relate to alterations in pulmonary and placental vascular resistance with advance in gestation.

Keywords: Cardiac time interval, Doppler echocardiography, fetus.

\section{Zusammenfassung}

Bestimmung von fetalen cardialen Zeitintervallen durch Doppler-Echocardiographie

Bei 88 normalen Feten zwischen der 16. und 41. Schwangerschaftswoche wurden 111 Untersuchungen mit der Doppler-Echocardiographie durchgeführt. Für jede Flowgeschwindigkeits-Kurve wurden die maximalen Geschwindigkeiten (MV) in der Aorta und Pulmonalarterie, die Akzelerationszeit (AT), die Auswurfzeit (ET), die MV/AT-Ratio (Akzelerationsgeschwindigkeit = AV) und die AT/ET-Ratio in der Systole bestimmt. Die MV in Aorta und Pulmonalarterie korrelierten gut mit dem
Gestationsalter. Auch zwischen der AT in Aorta und Pulmonalarterie und dem Gestationsalter bestand eine auffällig gute Korrelation. Ebenso zeigte sich eine Korrelation zwischen der AT/ET-Ratio in Aorta und Pulmonalarterie und dem Gestationsalter. Nicht mit dem Gestationsalter korrelierten jedoch AV und ET in der Aorta sowie AV und ET in der Pulmonalarterie. Möglicherweise sind diese Befunde auf mit zunehmenden Schwangerschaftsalter auftretende Veränderungen des Gefäßwiderstandes in Lunge und Plazenta zurückzuführen.

Schlüsselwörter: Cardiales Zeitintervall, Doppler-Echocardiographie, Fet. 


\section{Résumé}

Intervalles de temps cardiaques fœtaux determinés par échocardiographie Doppler

On a réalisé cent onze examens échocardiographiques doppler chez 88 fœtus normaux, entre 16 et 41 semaines de gestation. On a déterminé sur chaque onde de vélocité sanguine la vélocité maximale aortique et pulmonaire (MV), le temps d'accélération (AT), le temps d'éjection $(\mathrm{ET}), \mathrm{MV} / \mathrm{AT}$ (vélocité d'accélération $=\mathrm{AV}$ ) et le ratio AT/ET systolique. La MV aortique et la MV pulmonaire sont chacunes bien corrélées avec l'âge gestationnel. De bonnes corrélations entre l'AT aortique, l'AT pulmonaire et l'âge gestationnel sont évidentes. Il y a des corrélations entre la ratio $\mathrm{AT} / \mathrm{ET}$ aortique, le ratio $\mathrm{AT} / \mathrm{ET}$ pulmonaire et l'âge gestationnel? Néanmmoins, il n'y a pas de corrélation entre l'AV aortique, l'ET aortique, l'AV pulmonaire, l'ET pulonaire et l'âge gestationnel. Ces données peuvent traduire des altérations au niveau des résitances vasculaires pulmonaires et placentaires avec l'évolution de la grossesse.

Mots-clés: Échocardiographie Doppler, fœtus, intervalle de temps cardiaque.

Acknowledgements: We thank M. Ohara for comments and K. MiHARA and M. Nisho for secretarial services.

\section{References}

[1] Cassin S, GS Dawes, BB Ross: Pulmonary blood and vascular resistance in immature foetal lambs. $J$ Physiol London 171 (1964) 80

[2] DAwes GS: The umbilical circulation. In: Dawes GS: Fetal and neonatal physiology, Year Book, Chicago 1968

[3] Giles WB, B TRUdINGER, PJ BAIRD: Fetal umbilical artery waveform and placental resistance: Pathological correlation. Br J Obstet Gynaecol 92 (1985) 31

[4] Hata T, K Hata, M KitaO: Fetal intracardiac blood-flow patterns assessed by pulsed Doppler and B-mode ultrasound. J Cardiovasc Ultrasonog 3 (1984) 101

[5] Hata T, S Aoki, K Hata, F Murao, M Kitao: Fetal intracardiac blood flow velocity waveforms assessed by continuous Doppler ultrasound. J Cardiovasc Ultrasonog 5 (1986) 203

[6] HATA T, S AOKI, K HATA, M Kitao: Intracardiac blood flow velocity waveforms in normal fetuses in utero. Am J Cardiol 59 (1987) 464

[7] Huhta JC, JF Strasburger, RJ Carpenter, A REITER, E ABINDER: Pulsed Doppler fetal echocardiography. J Clin Ultrasound 13 (1985) 247

[8] Kenny JF, T Plappert, P Doubilet, DH SaltgMAN, M Cartier, L Zollars, GF Leatherman, MG St. JoHN Sutron: Changes in intracardiac blood flow velocities and right and left ventricular stroke volumes with gestational age in the normal human fetus: A prospective Doppler echocardiographic study. Circulation 74 (1986) 1208

[9] Kitabatake A, M Inoue, M Asao, T Masuyama, J TANOUChi, T Morita, M Mishima, M Uematsu, T Shimazu, M Hori, H ABE: Noninvasive evaluation of pulmonary hypertension by a pulsed Doppler technique: Circulation 68 (1983) 302
[10] Kosturakis D, SJ Goldberg, HD Allen, C LoeBER: Doppler echocardiographic prediction of pulmonary arterial hypertension in congenital heart disease. Am J Cardiol 53 (1984) 1110

[11] Machodo MVL, SC Chita, LD Allan: Acceleration time in the aorta and pulmonary artery measured by Doppler echocardiography in the midtrimester human fetus. Br Heart J 58 (1987) 15

[12] Maulik D, NC Nanda, VD Salini: Fetal Doppler echocardiography: Methods and characterization of normal and abnormal hemodynamics. Am J Cardiol 53 (1984) 572

[13] Maulik D, NC Nanda, S Moodley, VD Saini, HA THIEDE: Application of Doppler echocardiography in the assessment of fetal cardiac disease. Am J Obstet Gynecol 151 (1985) 951

[14] Nakazawa T: Studies on assessment of fetal growth by ultrasound fetal growth by ultrasound fetal cephalometry. Acta Obst Gynaec Jpn 25 (1973) 873

[15] OKamoto M, K Miyatake, N Kinoshita, H SaKAKIBARA, Y NimURA: Analysis of blood flow in pulmonary hypertension with the pulsed Doppler flowmeter combined with cross sectional echocardiography. Br Heart J 51 (1984) 407

[16] ReEd KL, EJ Meijboom, DJ SaHn, SA Scagnelli, LM Valdes-Cruz, L Shenker: Cardiac Doppler flow velocities in human fetuses. Circulation 73 (1986) 41

[17] ReED, KL, DJ SAHN, S Scagnelli, CF Anderson, L SHENKER: Doppler echocardiographic studies of diastolic function in the human fetal heart: changes during gestation. J Am Coll Cardiol 8 (1986) 391

[18] RudolPh AM, MA Heymann: Circulatory changes during growth in the fetal lamb. Circ Res 26 (1970) 289 
[19] Sato A, M Akama, H Yamanobe, K Hoshi, M SUZUKI: Intrauterine growth of live-born Japenese infants between 28 and 42 weeks of gestation. Acta Obst Gynaec Jpn 34 (1982) 1535

[20] Serwer GA, AG Cougle, JM Eckerd, BE ArmSTRONG: Factors affecting use of the Doppler-determined time from flow onset to maximal pulmonary artery velocity for measurement of pulmonary artery pressure in children. Am J Cardiol 58 (1986) 352

[21] Trudinger BJ, WB Giles, CM CoOK, J BombarDIERI, L ColLINS: Fetal umbilical artery flow velocity waveforms and placental resistance: Clinical significance. Br J Obstet Gynaecol 92 (1984) 23
[22] Tsuzaki T, K Iwamoto, K Maeda: Significance in ultrasonographic measurement of fetal limb bones. Acta Obst Gynaec Jpn 34 (1982) 1535

Received October 20, 1988. Accepted December 13, 1988.

Toshiyuki Hata, M. D.

Department of Obstetrics and Gynecology

Shimane Medical University

Izumo 693, Japan 